Journal of Engineering and Applied Sciences 14 (Special Issue 7): 10162-10168, 2019

ISSN: 1816-949X

(c) Medwell Journals, 2019

\title{
Government Spending and Economic Growth in Rental Countries: Dynamics of Conjugation and Correlation
}

\author{
${ }^{1}$ Haidar A.H. Al-Jubouri and ${ }^{2}$ Hayder H. Tuama \\ ${ }^{1}$ Department of Metals Engineering, College of Materials Engineering, \\ University of Babylon, Hillah, Iraq \\ ${ }^{2}$ College of Administration and Economics, University of Karbala, Karbala, Iraq
}

\begin{abstract}
The relationship between trends in public spending and economic performance remains controversial and controversial at the level of economic theory and empirical studies in both developing and developed countries. In the oil countries, public spending plays multiple roles in economic activity, the most important being the engine of economic growth and stability and a tool to distribute the revenues of the oil supplier to various segments of society as well as being the channel between the fluctuations of oil prices and the direction of the economic cycle in these countries. This study attempts to reveal the dynamic relationship between government expenditure and economic growth, expressed in GDP at constant prices in the Iraqi economy during the period 1990-2015 using the model of joint integration and the rationale of the granger using annual and quarterly data. The results revealed a long-term equilibrium relationship between the above variables. Government spending has an influential role in economic growth in the short and long term. Finally, the Granger test of causality from government spending towards GDP as expected in oil-exporting countries, the oil resource in moving the economy through the channel of government spending both current and investment.
\end{abstract}

Key words: Government spending, rental countries, economic theory, conjugation and correlation, GDP, oil resource

\section{INTRODUCTION}

The failure of development in resource-rich countries has attracted a great deal of attention to the emergence of analysis models that address this problem. The literature had earlier spoken of one of the rich countries in gold and his experience was surprising as it became 20 years after the extraction and export of gold is poorer than before.

This phenomenon has been repeated in other countries in different ways in some cases to the extent of proving the inverse relationship between richness of natural resources and development. The economic importance of public spending in developing countries is increasing due to the expanding economic and social role of the state. In oil countries, other roles are added, perhaps the most important of which is that public spending is a tool for distributing oil revenues to the public. The economic experience in the oil countries reveals a unique growth model where government expenditure is an engine for most economic sectors and a chief employer. Even for the private sector (non-oil), it is indirectly living on oil by relying on the salaries of state employees and contracting it mainly with government institutions which resulted in a tight correlation between the movement of the oil sector and the non-oil sector in these countries. One of the most important challenges facing Iraq's oil economy is its dependence on government spending as a major source of household income and the inability of the market mechanisms to move the private sector to direct productive investment in a manner appropriate to modernize the national economy. The effort to sustain the current expenditures in the budget and stabilize the living standards of the families and the experience of Iraq is sufficient to clarify the negative role of fluctuations of the oil resource. When oil supplies rise, consumption and investment rise but the decline is usually at the expense of investment. Financial policy usually faces strong social pressures to increase spending as the oil resource increases to expand immediate consumer use of additional resources, to develop infrastructure and expand public services. The financial administration of the oil countries including Iraq has noticed early on the danger of increased public spending financed by the oil source as evidenced by some countries adopting the non-oil deficit measure, the difference between government spending

Corresponding Author: Haidar A.H. Al-Jubouri, Department of Metals Engineering, College of Materials Engineering, University of Babylon, Hillah, Iraq 
and non-oil revenues. In Iraq, the current budget deficit index has been in circulation, since, early which means comparing non-investment expenditures with non-oil revenues in the hope of developing tax revenues and profits of public companies and the like. This study examines the dynamics of the relationship between government expenditure and the economic growth momentum in a rural economy. The first part deals with the nature of the relationship between spending and GDP. The theories that explain the relationship between these variables will be discussed. And finally, follow the trends of public spending in the oil-exporting countries and the most prominent roles played by current and investment spending on the structure of the national economy. The second section deals with measuring the relationship between government expenditure and economic growth in Iraq by using modern models in the analysis of the time series (annual and quarterly) of the variables of the study to verify the role of public expenditure in growth and economic stability and thus, to formulate appropriate economic policies to maintain the sustainability and stability of public expenditure and isolate it from fluctuations in oil revenues.

\section{Literature review}

The relationship of expenditure to growth in the context of economic theory: The second half of the twentieth century saw many studies and research attempts to explain and develop the theory of economic growth in developing countries. The role of dynamo's drivers of economic growth was emphasized and government expenditure was one of the most prominent elements. Macroeconomic theory reveals a relationship between government spending and economic growth expressed in GDP. But the nature and direction of this relationship has been the subject of debate and debate between various modern and contemporary economic schools (Alshahrani and Alsadiq, 2014). However, the focus of applied studies and research is to examine the relationship between government spending and economic growth between Wagner's law and Keynesian hypothesis. Wagner's law refers to the economic economist Adolf Wagner who pointed out that the causation trend in this relationship stems from GDP to government expenditure as the increase in economic growth rates lead to the expansion of state activity and increase government expenditure by more than the rate of increase in the average per capita GDP under this law, government spending is an endogenous variable and a function of economic growth. The Keynesian hypothesis points to a positive relationship between public spending and economic growth. The increase in public expenditure increases the national income doubly through the mechanism of the multiplier. According to this hypothesis, exogenous variable income causes economic growth in income national. It emerges from the following four sector model which shows the level of equilibrium income when the total supply (output) is equal to the total demand (expenditure):

Where:

$$
\mathrm{Y}=\mathrm{C}+\mathrm{I}+\mathrm{G}+\mathrm{X}-\mathrm{M}
$$

$\mathrm{G}=$ The Government expenditure

$\mathrm{I}=$ The Private Investment

$\mathrm{C}=$ The private Consumption

$\mathrm{X}-\mathrm{M}=$ The net exports

$\mathrm{Y}=$ The gross income

Thus, according to Keynes's theory of effective demand, the causality of the relationship takes the path that extends from government spending to GDP in contrast to the Wagner Act (HusniSbeih, 2015).

Trends in public spending in oil countries: Public expenditure in rent economies is very large. They are subject to the phenomenon of continuous increase whether this increase expressed in absolute numbers or percentages to GDP. Public expenditure has witnessed a significant expansion in most oil countries in order to achieve the objectives of development, economic stability, equitable distribution of income, satisfaction of public needs and other matters that the state has to implement and carry out. There are several reasons for increasing public expenditures, the most important of which are Al-Tai (2011).

The number of people in these countries is increasing due to the improvement in the health and living conditions in them which has been positively reflected in the increase in population growth and the increase in public expenditure. They follow an employment policy that is not subject to the principle of cost-saving which has been reflected in increased employment rates, leading to a convincing unemployment rate accompanied by increased public expenditure on wages, salaries, pensions and other in-kind benefits.

Because of the oil reserves of these countries and the importance of these rent resources in the global energy market due to the increasing global demand for oil by the various countries of the world, the flow of dollar revenues is increasing and the government's tendency to expand public spending for political and economic purposes and social issues. 


\section{J. Eng. Applied Sci., 14 (Special Issue 7): 10162-10168, 2019}

The requirements for the advancement of the development reality have played a major role in increasing public expenditure in rent countries. The economic reality of these countries with their enormous potential and resources, enabled them to move towards rapid economic development plans for the past decades. In the oil rent countries, the existence of oil reserves and the possibility of exporting them in exchange for prices exceeding the cost of production is a huge revenue to be able to support the expenditure requirements for all the society's activities and needs.

High borrowing ability has played an active role in encouraging the rentier countries to expand public expenditure because of the huge amount of money they provide. This is because of the behavior of Foreign banks in providing all credit facilities and overcoming all obstacles to these countries in granting loans. On concessional or unconditional terms being able to repay and to meet their obligations at any time because of their proven oil reserves which has led to an increase in the volume of borrowed funds and debt and debt servicing. These funds have been directed to the expansion of public spending significantly and have exceeded the level of Wei rates of gross domestic product in most of those countries.

Public expenditures are characterized by their ability to redistribute or direct rents to sectors or social groups. Through this role, the state has become the guardian and guide of the economy. The reason is that the rent flowing on the coffers of these countries from external sources gives them the opportunity to take control of all areas and levels with the huge financial strength and then expand their public expenditure to include all economic, social, political and this gives the public expenditure the status of inclusiveness, the aim of the state is to satisfy collective rather than individual needs such as education, health, security and social security, given the comprehensive benefits of all members of society.

The dynamics of the relationship between spending and growth in rent economies: Between 1960 and 2000, oil-exporting countries experienced less average growth rates than the group of developing countries and the group of non-oil-exporting countries. Despite the high flow of oil revenues in most of these countries (El-Anshasy, 2012). Oil countries have not taken sound policies to shift from extractive, distribution-based rental economies to labor-intensive and productive economies, diversification of activities and exports and the diversion of depleted natural resources to assets that generate sustainable economic growth. The pattern of growth in these countries depends on oil revenues redistributed in the economy through the government spending mechanism. Part of this expenditure is related to public wages and salaries in the public sector and part of it is related to capital expenditure (investment) in development projects, infrastructure and social services. Private sector activity after four decades of oil exports remains concentrated in three main areas: contracting, services and import of Foreign goods, taking advantage of huge government spending in times of oil boom, government capital and cheap energy inputs. The private sector is seeking rapid profits from the oil boom through its associated public spending savings. While most citizens are employed by the state in a weak, inefficient and productive public sector, they receive salaries that spend most of it in consumer demand from private sector output. The private sector therefore benefits from direct government spending through government contracting and procurement and indirectly from current expenditure through public sector salaries and wages which later constitute consumer demand for private sector products. With oil spikes and rising capital expenditure, a large part of the capital and investments generated by these oil spills go to the non-traded sector; services, in particular which lead to the competition of the tradable sector, contribute to the diversification of exports and do not generate high added value for production, nor sustainable growth after bubble bursts and the eruption of mutations (Ahmad and Masan, 2015). It is clear that, this growth model is biased by its concentration in the non-traded goods sector, to achieve rapid profits from oil and government spending through cheap and profit-based investment based on low-wage Foreign labor in semi-monopolistic local markets rather than entry risk In a competitive Foreign export market that requires high technical and managerial skills, innovation and development to remain competitive. It is noted that this model leads to greater concentration in economies with mutations and to low productivity in the public and private sectors as evidenced by the evidence (Al Khater, 2015). The government effort in these countries to maintain the current expenditure in the budget and stability of living standards of families and the experience of Iraq is sufficient to clarify the negative role of fluctuations of the oil resource. When oil supplies rise, consumption and investment rise but the decline is usually at the expense of investment. The oil economy is accustomed to coexist with the overvaluation of the national currency and hence, the Dutch disease, the low level of international competitiveness in the activities of traded goods. On the other hand, the distribution of the oil resource has an additional role in diverting the activities of goods traded in favor of services because citizens find 


\section{J. Eng. Applied Sci., 14 (Special Issue 7): 10162-10168, 2019}

in the public sector the desired employment opportunities and lucrative salaries. Companies find investment in the production of goods and services that respond to domestic investment and consumption demand is more feasible and less risky than export oriented production. Therefore, diversifying the productive base does not mean diversification of exports which is the objective. In other words, the feasibility of investment in terms of return and risk is biased towards non-traded goods and services by virtue of not being exposed to external competition. Investments that tend to produce retail goods for export are mostly for the public sector and are concentrated on oil and gas resources because the comparative advantage here helps to compete. Although, huge investment programs are being implemented in the Gulf countries to build large capacity in petrochemicals and energyintensive industries, growth is still dependent on government spending from the oil supplier, a pattern well known in Iraq (Ali, 2012). The failure of development in countries rich in natural resources has attracted so much attention that analytical models are emerging to address this problem. There are several hypothesis to explain this phenomenon, the first is the Dutch disease which means that exports of natural resources lead to the abundance of Foreign currency which leads to the appreciation of the local currency coupled with the decline in the relative price of goods traded to non-traded goods and this leads to the deterioration of the international competitiveness of the country which leads to a relative contraction in the commodity production sector in favor of Foreign imports. The second hypothesis is called the resource curse or the paradox of abundance. This hypothesis is based on the observation of exaggerating government spending without calculating the fluctuations in the level of revenue. Since, public spending when it rises can not be easily reduced, current spending rises with every jump in natural resource due to the low propensity to save from the natural resource. The country is increasingly exposed to financial crises and therefore has to borrow (Venezuela and Mexico, for example) and thus, gradually departs from the requirements of development. In the context of this "resource curse" hypothesis, the damage to rent behaviour is often emphasized and the accumulation of wealth from the practice of marginal activities do not require capital or risk and away from the fields that serve development or questionable in the economic level of the overall the behaviour of rent in the context of that enduring, overshadows the administrative apparatus of the state and manifestations of mismanagement and financial corruption extends to NGOs and private companies (Ali, 2016).

\section{MATERIALS AND METHODS}

The data and the standard model used: The study is based on a methodology aimed at linking the theoretical and experimental bases and will depend on the analytical method to evaluate the results of the experimental research. The economic analysis derived from the theoretical and empirical studies that dealt with the developmental effects of government spending was based on economic analysis. Annual and quarterly time series have been used for both government spending and Gross Domestic Product (GDP) at constant prices to measure the impact of public spending on economic growth in Iraq. The first time series for the period (1990-2015/annual data) and the duration of 26 views. The second time series extends for the period 2010 (Q1-2016.Q4/Quarterly data) and with 28 observations. Data from the Ministry of Finance, the economic department were based on the tables of final accounts. And publications of the Ministry of Planning and Development Cooperation, the Central Bureau of Statistics. And the Central Bank of Iraq, the General Directorate of Statistics and Research, scattered bulletins. The statistical program (EViews-9.1) was used to test and analyze the time series of the study variables.

\section{RESULTS AND DISCUSSION}

Test the stability of time series: The Augmented Dickey-Fuller test was used to test the dormancy of study variables and for both annual and quarterly series (Enders, 1995). The results of the calculated values of $\tau$ for the level of government Expenditure (EX) and GDP. Table 1 shows that all the calculated values of the levels of variables (either fixed or constant and general) $\left(\mathrm{H}_{0}: \beta=0\right)$ for each of the time series levels during the study period (Dickey and Fuller, 1981). Thus, the time series (annual and quarterly) of the variable government Expenditure (EX) and GDP in Iraq are not stable time series at the general level.

On the other hand, the results in Table 2 indicate that the null hypothesis $\left(\mathrm{H}_{0}: \beta=0\right)$ was rejected at a significant level 1, 5 and 10\%. EX and Gross Domestic Product (GDP) in Iraq from the root of the unit after taking the first differences. Therefore, the variables of the study are integrated first class and stable at the first differences and then the possibility of integrating them together.

The test of joint integration: Several standard approaches are used to test the common integration of time series such as the Engel-Granger two step method and the Johansson methodology. The Johansen method is one of the most important standard approaches used to test the common integration of time series. This test 
J. Eng. Applied Sci., 14 (Special Issue 7): 10162-10168, 2019

Table 1: Augmented Dickey-Fuller unit root test (prepared by researchers based on EViews-9.1)

\begin{tabular}{|c|c|c|c|c|}
\hline \multirow[b]{2}{*}{ Augmented Dickey-Fuller tests } & \multicolumn{2}{|l|}{ Annual } & \multicolumn{2}{|l|}{ Quarterly } \\
\hline & Constant only & Intercept and trends & Constant only & Intercept and trends \\
\hline \multicolumn{5}{|l|}{ Level } \\
\hline EX & -1.510576 & -3.470915 & -1.994972 & -1.863169 \\
\hline GDP & -0.416955 & -2.943703 & -1.830821 & -1.854525 \\
\hline \multicolumn{5}{|l|}{ Critical values (Levels \%) } \\
\hline 10 & -3.724070 & -4.374307 & -3.711457 & -4.356068 \\
\hline 10 & -2.986225 & -3.603202 & -2.981038 & -3.595026 \\
\hline 10 & -2.632604 & -3.238054 & -2.629906 & -3.233456 \\
\hline
\end{tabular}

Table 2: Augmented Dickey-Fuller unit root test (prepared by researchers based on EViews-9.1)

\begin{tabular}{|c|c|c|c|c|}
\hline \multirow[b]{2}{*}{ Augmented Dickey-Fuller tests } & \multicolumn{2}{|l|}{ Annual } & \multicolumn{2}{|l|}{ Quarterly } \\
\hline & Constant only & Intercept and trends & Constant only & Intercept and trends \\
\hline \multicolumn{5}{|l|}{ Augmented } \\
\hline EX & -6.057452 & -6.001579 & -8.887630 & -8.574685 \\
\hline GDP & -4.932824 & -4.742634 & -6.271045 & -6.269919 \\
\hline \multicolumn{5}{|l|}{ Critical values (Levels \%) } \\
\hline 10 & -3.737853 & -4.394309 & -3.737853 & -4.394309 \\
\hline 10 & -2.991878 & -3.612199 & -2.991878 & -3.612199 \\
\hline 10 & -2.635542 & -3.243079 & -2.635542 & -3.243079 \\
\hline
\end{tabular}

involves estimating the Vector Autoregressive Model (VAR) Model using the maximum likelihood function. This model was developed (Johansen, 1988; Johansen and Juselius, 1990) to avoid the shortcomings of the methodology of the steps for Angel and Ganger. This test is superior to the Engel and Ganger integration test because it is suitable for small samples as well as if there are more than two variables. More importantly, the Johansen-Jesleus test reveals whether there is more than one vector of cointegration in the relationship. In order to determine the number of integration vectors, two statistical tests based on the maximum likelihood function are used: the trace test and the maximum eigen values test. As Table 3 and 4 show the results of the $\lambda$ trace and the $\lambda$ max test to analyze the (annual and quarterly) relationship between government spending (EX) and GDP in Iraq. The results indicate that the calculated value of the $\lambda$ trace for the annual and quarterly data was 16.34407 and 27.12040 , respectively which exceeds the critical values 15.49471 and 15.49471 at a significant level $(5 \%),(\mathrm{R}=0)$ and acceptance of the alternative hypothesis that a number of cointegration integers are greater than zero $(r=1)$. It is also possible to reject the null hypothesis that $(\mathrm{r}=11)$ is at a significant level (5\%) for annual and quarterly data, thus, there is no second cointegration vector. The results show that the calculated value of the effect test $0.42965,2.430242$ of the critical value 3.841466 and 3.841466 at a significant level 5\%.

On the other hand, the results of the $\lambda$ max test were identical to the results of the impact test with one vector for the combined integration of government spending (EX) and GDP in Iraq. The results of Table 4 shows that the calculated values of the potential rate for the annual and
Table 3: Johansen cointegration test (Trace) (prepared by researchers based on EViews-9.1)

\begin{tabular}{|c|c|c|c|c|}
\hline Hypothesis No. & Eigen values & Trace stat & CV (5\%) & Probabilities \\
\hline \multicolumn{5}{|c|}{ Annual } \\
\hline$r=0$ & 0.484033 & 16.34407 & 15.49471 & 0.0372 \\
\hline$r \leq 1$ & 0.019105 & 0.462965 & 3.841466 & 0.4962 \\
\hline \multicolumn{5}{|l|}{ Quarterly } \\
\hline$r=0$ & 0.613113 & 27.12040 & 15.49471 & 0.0006 \\
\hline$r \leq 1$ & 0.019105 & 2.430242 & 3.841466 & 0.1190 \\
\hline
\end{tabular}

Table 4: Johansen cointegration test (maximum eigenvalue)(prepared by researchers based on EViews-9.1)

\begin{tabular}{llll}
\hline Hypothesis No. Eigen values & Max-Eigen stat & CV (5\%) & Probabilities \\
\hline
\end{tabular} Annual

$\begin{array}{lllll}r=0 & 0.484033 & 15.88111 & 14.26460 & 0.0275\end{array}$

$\begin{array}{lllll}\mathrm{r} \leq 1 & 0.019105 & 0.462965 & 3.841466 & 0.4962\end{array}$

Quarterly

$\begin{array}{lllll}\mathrm{r}=0 & 0.613113 & 24.69016 & 14.26460 & 0.0008\end{array}$

\begin{tabular}{lllll}
$\mathrm{r} \leq 1$ & 0.089235 & 2.430242 & 3.841466 & 0.1190 \\
\hline
\end{tabular}

quarterly data were 15.88111 and 24.69016, respectively, higher than the critical values (14.26460 and 14.26460) at a significant level $(5 \%)(\mathrm{R}=0)$ and acceptance of the alternative hypothesis that there is a single vector of co-integration $(r=1)$. Finally, with respect to the second vector, the results showed that the calculated values for the test of the maximum value (for annual and quarterly data) were 0.466965 (2.430242), smaller than the critical value 3.84 and 3.84 at a significant level (5\%). $\mathrm{H}_{0}: \beta=0$ indicating that there is no second vector of co-integration and rejecting the alternative hypothesis $(r>1)$. This means that there is a long-term (one-way) balance between government Expenditure (EX) and GDP in Iraq during the study period (annual and quarterly), although, there is a short-term imbalance (Fig. 1). 


\section{J. Eng. Applied Sci., 14 (Special Issue 7): 10162-10168, 2019}

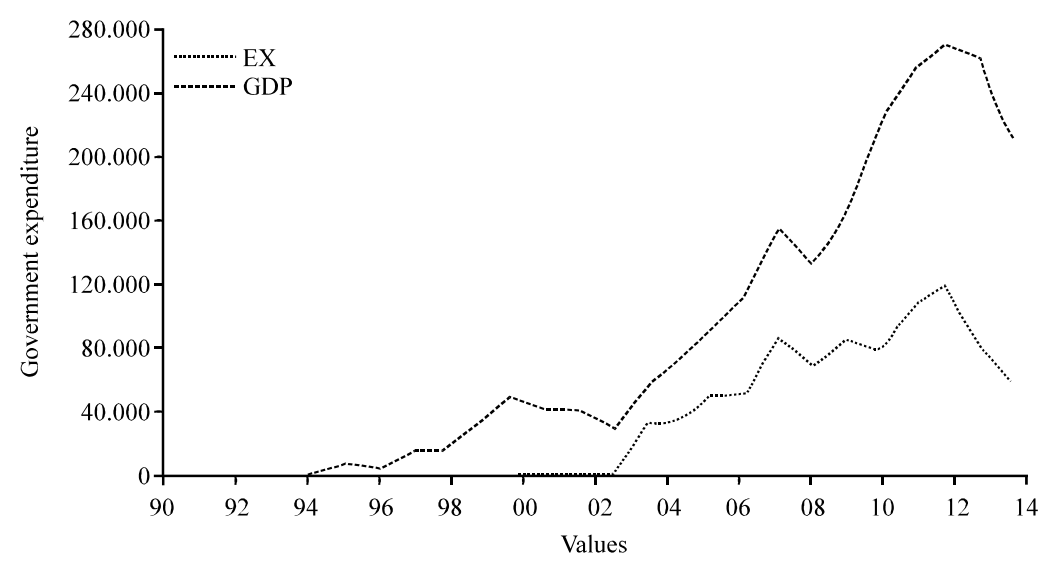

Fig. 1: The long-term balance between government expenditure and GDP in Iraq (prepared by researchers based on EViews-9.1)

Table 5: Pairwise Granger causality test result

\begin{tabular}{llccc}
\hline Null hypothesis & Lags & F-statistics & Probabilities & Decisions \\
\hline EX does not Granger cause GDP & 1 & 6.67876 & 0.0057 & Reject \\
GDP does not Granger cause EX & & 0.45170 & 0.6426 & Accept \\
EX does not Granger cause GDP & 2 & 6.67876 & 0.0057 & Reject \\
GDP does not Granger cause EX & & 0.45170 & 0.6426 & Accept \\
EX does not Granger cause GDP & 3 & 7.98884 & 0.0012 & Reject \\
GDP does not Granger cause EX & & 0.50456 & 0.7331 & Accept \\
EX does not Granger cause GDP & 4 & 5.09497 & 0.0098 & Reject \\
GDP does not Granger cause EX & & 0.48785 & 0.7792 & Accept \\
\hline
\end{tabular}

Test the direction of causation: The causal relationship between government Expenditure (EX) and GDP in developed and developing countries has been subject to many economic studies that have reached inconclusive results. The theoretical debate and applied studies led to four explanatory trends of the assumed relationship between the following variables: suggest a un-directional causality from government spending to GDP based on the Keynesian hypothesis of total effective demand. The second view is attributable to the fluctuations in government spending to GDP fluctuations and thus there is an inverse correlation between GDP and government spending, based on Wagner's law. The third view is the bi-directional causality between government spending and GDP. This trend has been supported by quite a few applied studies. Finally, the fourth trend, led by the proponents of rational expectations school, confirms the lack of causal relationship between these variables, since, the developments in government spending and economic growth are largely driven by various factors as well as the neutrality of public expenditure financed by taxes on growth due to the Ricardian equivalence theory The impact of public spending financed by public borrowing is also weak due to the impact of financial competition.

Finally, it should be noted that the expected trend of causation in an oil economy stems from government spending towards economic growth. Government expenditure in rent countries is a main channel for the distribution of rent resources and a driver for the growth and sustainability of various governmental and private economic sectors, directly and indirectly. According to Granger, the existence of the combined integration of variables between government variables and output means that there is a causal relationship in at least one direction but determining the direction of the causal relationship between the variables studied requires the use of Granger's causality. This test is used to determine the direction of causality between economic variables and also to show that the change in the current values of a variable causes change in another variable (Granger, 1969). In other words, the change in current and past government spending (EX) values causes a change in the GDP values.

The results of the causality test in Table 5 show that changes in government Expenditure (EX) help to explain changes in Gross Domestic Product (GDP) and for all periods of slowdown at a significant level (1\%). This is in line with the model of economic growth in the oil countries and the role played by oil resources in financing the budget and sustaining the economic momentum through the government spending channel (both current and investment). This result is consistent with the structure of the Iraqi economy and is largely based on public spending with government spending amounting to about $70 \%$ of GDP. 


\section{J. Eng. Applied Sci., 14 (Special Issue 7): 10162-10168, 2019}

\section{CONCLUSION}

In oil countries, the financial structure is almost entirely tied to oil. Excessive dependence on oil in covering public expenditure has been compounded by other government revenues such as taxes, duties and revenues of public economic institutions and weaker contribution to public budget financing. This reality generated a serious exposure to public expenditure on oil revenue revenues and is mainly related to fluctuations in oil prices which are directed by factors and changes in economic and political world.

In Iraq, previous governments have lost decades of development despite the availability of the necessary capital to launch the national economy and meet the requirements of development and stability in various economic sectors. Despite the multiplicity of reasons behind the failure of the development efforts of the government but the element of financial exposure to the economy and the budget on oil was at the forefront of these reasons as the reflection of price fluctuations of global energy markets on the path of development and stability through a series of channels which reflected the fluctuations of oil prices in the development mode winding and public spending was one of the most important channels. As it is the engine of growth and economic stability and a tool for the distribution of oil revenues and the sector leading to most non-oil sectors, government and private. This study attempted to verify the roles played by public expenditure on economic growth rates in Iraq in the long and short term by analyzing the time series of the variable of government expenditure and the variable of gross domestic product at constant prices by testing them in modern standard models. Joint integration finally use causative granger. The results revealed a long-term equilibrium relationship with long-term variables (annual data) and short term (quarterly data). The causation trend was from government expenditure to GDP and to the various deceleration periods used government spending is driving growth and economic stability in Iraq.

These results oblige the economic decision-makers in Iraq to reconsider the existing growth model and reduce the financial exposure of public expenditure on the world oil markets to isolate the trends of government spending (both current and investment) on the winding path of oil prices. As well as the need to raise the efficiency and effectiveness of public spending and try to reduce the economic role of the state in favor of growth and stimulate the private sector to be the engine of growth and source of employment generation.

\section{REFERENCES}

Ahmad, A.H. and S. Masan, 2015. Dynamic relationships between oil revenue, government spending and economic growth in Oman. Intl. J. Bus. Econ. Dev., 3: 93-115.

Al Khater, K.R., 2015. The challenges of the collapse of oil prices and economic diversification in the GCC countries. Master's Thesis, Arab Center for Research and Policy Studies, Doha, Qatar.

Al-Tai, W.K.J., 2011. Public expenditures in the rental economies trends and reflections. Master Thesis, Al-Mustansiriya University, Baghdad, Iraq.

Ali, A., 2012. International Financial Economy and Monetary Policy. Hammurabi Center for Research and Strategic Studies, Baghdad, Iraq, Pages: 87.

Ali, A.A., 2016. Financing, Exchange and Development in an Oil Economy. Dar Al-Ayyam, Amman, Jordan.

Alshahrani, M.S.A. and M.A.J. Alsadiq, 2014. Economic Growth and Government Spending in Saudi Arabia: An Empirical Investigation. International Monetary Fund, Washington, D.C., USA., ISBN: 9781484348796.

Dickey, D.A. and W.A. Fuller, 1981. Likelihood ratio statistics for autoregressive time series with a unit root. Econ. J. Econ. Soc., 49: 1057-1072.

El-Anshasy, A.A., 2012. Oil prices and economic growth in oil-exporting countries. J. Policy Model., Vol. 34,

Enders, W., 1995. Applied Econometrics Time Series: A User's Guide. John Wiley \& sons, Inc., New York, USA., ISBN-13:9780471111634.

Granger, C.W.J., 1969. Investigating causal relations by econometric models and cross-spectral methods. Econometrica, 37: 424-438.

HusniSbeih, M., 2015. Analysis of the effect of government expenditure on gross domestic product in the palestinian economy. Arab Econ. Res. J. Center Arab Unity Stud., 1: 98-98.

Johansen, S. and K. Juselius, 1990. Maximum likelihood estimation and inference on co-integrated with applications to the demand for the money. Oxford Bull. Econ. Stat., 52: 169-210.

Johansen, S., 1988. Statistical analysis of cointegration vectors. J. Econ. Dyn. Control, 12: 231-254. 